\title{
Which Is The Fairest Between Civil Inheritance Law, Customary Inheritance Law or Islamic Inheritance Law?
}

\author{
Rachmat Trijono \\ Ministry of Law and Human Rights, Indonesia \\ Lkpi.179@gmail.com
}

\begin{abstract}
:
Basically, inheritance law is closely related to the scope of human life, because every human being will certainly experience a legal event called death. Inheritance law in Indonesia is very diverse, namely civil inheritance law, customary inheritance law, and inheritance law according to Islamic Teachings. The purpose of this research is to find out the fairest inheritance law, between civil inheritance law, customary inheritance law, or Islamic inheritance law. The problem under investigation is which one the fairest? The method that used in this research is qualitative method with a utility approach. The results showed that none inheritance law is fairest, civil inheritance law, customary inheritance law or Islamic inheritance law that fair. Everything is fair according to its usefulness. Civil inheritance law is fair if used for those who use it, Islamic inheritance law is fair to those who are Muslim and customary inheritance law is fair for those who apply it. The advice given is the application of inheritance law should be adjusted according to its usefulness.
\end{abstract}

Keywords: Inheritance Law, Civil Inheritance Law, Customary Inheritance Law, Islamic Inheritance Law.

\section{INTRODUCTION}

\section{Background and Problem}

Indonesia is an archipelago in Southeast Asia that has 17,504 large and small islands, around 6,000 of which are uninhabited, which spread around the equator, which provides tropical weather. Indonesia's position is located at coordinates $6^{\circ} \mathrm{N}-11^{\circ} 08^{\prime} \mathrm{LS}$ and from $95^{\circ}$ 'East $141^{\circ} 45^{\prime} \mathrm{BT}$ and is located between two continents, Asia and Australia / Oceania (Prasetya, 2017). Indonesia's territory extends along 3,977 miles between the Indian Ocean and the Pacific Ocean. The land area of Indonesia is $1,922,570 \mathrm{~km}^{2}$ and the area of its waters is $3,257,483 \mathrm{~km}^{2}$ (UN Convention on the Law of The Sea, 1982).

Islam is the majority religion that is embraced by around $87 \%$ of Indonesia's population, which makes Indonesia the country with the most Muslim population in the world. The rest are Protestants (7\%), Catholics (3\%), Hindus (1.7\%), Buddhists (0, 7\%), Confucianism and others (0.5\%) (BPS, 2016). 
Indonesia has three inheritance laws, namely civil inheritance law, customary inheritance law, and Islamic inheritance law. (1) inheritance law contained in the Book Civil Law (BW), Books I Chapter XII to Chapter XVIII from Article 830 to Article 1130, (2) inheritance law contained in Customary law, namely in the Customary inheritance law section, and (3) inheritance law that is contained in Islamic inheritance law, namely the provisions of inheritance law in Islamic fiqh called mawaris or faraidh or Islamic Law Compilation (KHI).

The difference in the apportionment of inheritance between civil inheritance law, customary inheritance law, and Islamic inheritance law raises a fundamental question, which inheritance law is the fairest?

\section{Theoretical Framework}

Utilitarianism was first developed by Jeremy Bentham (1748-1831) (Bentham, 2000). The problem that Bentham faced at that time was a poor assessment of social policy, economics, and moral law. In other words, how to judge a public policy that has many moral ideas. Based on the thesis, Bentham found the most objective basis is to see whether there are certain policies or actions that bring benefits or beneficial results or vice versa, contrary to the people involved (Keraf, 1998, pp. 93-94).

When asking what Bentham stated in law, the pros and cons of the law must be considered from the pros and cons of the results produced by the application of the law. A new legal provision can be evaluated properly, if necessary - the results resulting from its application are profusely, profusely happiness, and increasingly less suffering. And conversely consider bad if applying it produces an unfair, a loss, and only adds to suffering. So it is not wrong that there are no experts who claim that the benefit theory uses this as an economic basis for legal thinking. The main principle of this theory is the purpose and legal considerations. The purpose of the law is as much as determined by the majority of the people or for all people, and the evaluation of the law is based on the results generated from the process of applying the law. Based on the agreement, the legal requirements are approval of state financial approvals (Rasjidi \& Putra, 1993, hal. 79-80).

\section{Method}

The method that used in this research is qualitative (Creswell, 2014) method with a utility approach. This study uses secondary data (Vartanian, 2011) obtained through the study of literature in the form of a variety of literature such as books, journals, the internet, and other reading sources. 


\section{Inheritance Apportionment}

As mentioned above that Indonesia has three inheritance laws namely civil inheritance law, customary inheritance law, and Islamic inheritance law, so there are differences in inheritance apportionment as follows:

\section{Civil Inheritance Law}

Indonesian civil inheritance law is part of the civil code. The core parts of this civil law consist of Person Law (Personnenrecht), Family Law (Familierecht), Property Law (Vermogensrecht) and Inheritance Law (Erfrecht). ${ }^{16}$

Civil Law in force in Indonesia until now still uses the provisions contained in the Civil Code / Civil Code (Burgerlijk Wetboek / BW). In the Civil Code, the inheritance law is part of the property law so that the legal arrangements are contained in Book II of the Civil Code on Objects.

Civil/Burgeleijke Wetbook (BW) inheritance law applies to Chinese and Europeans, Indigenous inheritance law applies to native Indonesians, while Islamic inheritance law applies to native Indonesians who are Muslim (Khisni, 2017).

\section{Understanding of the Civil Code Legacy Law}

The definition of inheritance law in the Civil Code in the Civil Code is not contained explicitly, but the legal experts provide or express the definition of inheritance law Civil Code. According to legal experts, specifically regarding Civil inheritance law as follows:

A. Pitlo stated that the Inheritance Law is: A collection of regulations governing the law regarding wealth due to someone's death, namely regarding the transfer of wealth left by the dead and the consequences of their relationship with them, as well as in their relationship with third parties (A.Pitlo, 1986, p. 1).

Wirjono Prodjodikoro, former Chairman of the Supreme Court of the Republic of Indonesia, stated: That inheritance law is the laws or regulations governing whether and how various rights and obligations regarding a person's wealth when he dies will be transferred to another person who is still alive (Ramulyo, 2004, p. 84). Civil inheritance apportionment as follow:

\section{TABLE I CIVIL INHERITANCE APPORTIONMENT}

\footnotetext{
${ }^{16}$ Indonesia, "Kitab Undang-Undang Hukum Perdata," n.d.
} 


\begin{tabular}{|c|c|}
\hline $\begin{array}{l}\text { Inheritance } \\
\text { Law }\end{array}$ & Inheritance Apportionment \\
\hline $\begin{array}{l}\text { Civil } \\
\text { Inheritance } \\
\text { Law }\end{array}$ & $\begin{array}{l}\text { 1. Group I, } \\
\text { Is an heir in a straight down line from the heir, namely the child, } \\
\text { husband/widower, wife/widow of the heir. The first-class heirs get the } \\
\text { right to inherit the second-class heirs, that is, as long as the first-class } \\
\text { heirs are still present, then the second-class heirs cannot appear. } \\
\text { 2. Group II } \\
\text { Is, the heir in a straight line up from the heir, that is, the father, mother } \\
\text { and brothers of the heir. This new heir appears to inherit if the heirs of } \\
\text { the first group do not exist at all by leaving the heirs of the third and } \\
\text { fourth groups. } \\
\text { 3. Group III } \\
\text { It is a blood family of the father or mother of the heir, that is, the } \\
\text { grandfather, grandmother, both the father or mother of the heir. In this } \\
\text { case, the heirs of the third group only have inheritance rights, if the heirs } \\
\text { of the first and second groups do not exist at all by putting aside the heirs } \\
\text { of the fourth group. } \\
\text { Is, Group IV }\end{array}$ \\
\hline
\end{tabular}

\section{Customary Inheritance Law}

Customary law is a set of customs, practices, and beliefs that are accepted as obligatory rules of conduct by indigenous peoples and local communities. Customary law forms an intrinsic part of their social and economic systems and way of life. What characterizes customary law is precisely that it consists of a group of customs that are recognized and shared collectively by a community, people, tribe, ethnic or religious group. This contrasts with written law emanating from a constituted political authority, the application of which is in the hands of that authority, generally the State (World Intellectual Property Organization, 2016). Customary inheritance apportionment as follow: 
TABLE II CUSTOMARY INHERITANCE APPORTIONMENT

\begin{tabular}{|c|c|}
\hline $\begin{array}{l}\text { Inheritance } \\
\text { Law }\end{array}$ & Inheritance Apportionment \\
\hline $\begin{array}{l}\text { Customary } \\
\text { Inheritance } \\
\text { Law }\end{array}$ & $\begin{array}{l}\text { 1. Heredity System, in this system, can be divided into three types, } \\
\text { namely the father's lineage, maternal lineage, and lineage } \\
\text { 2. The individual system is a type of inheritance distribution based on } \\
\text { their respective parts, mostly applied to the Javanese tribal community. } \\
\text { 3. Collective System, a system of inheritance distribution where each } \\
\text { heir has the right to obtain an inheritance or not receive an inheritance. } \\
\text { The form of inheritance used with this type is the inheritance in certain } \\
\text { communities. } \\
\text { 4. A majorate system is a system of inheritance distribution that is given } \\
\text { to children invited by the family. For example in the people of Lampung } \\
\text { and Bali. }\end{array}$ \\
\hline
\end{tabular}

\section{Islamic Inheritance Law}

In the provisions of Islamic law, the reasons for being able to accept the inheritance in general, namely: (a) kinship relations and (b) relationships marriage (Khisni, 2017). The legal basis of kinship as a provision that men and women both have inheritance rights as stated in the QS. Al-Nisa ': 7, "For men, there is a right part of the inheritance of the mother, father and their relatives, and for women, there is a right (part) of inheritance ladies and gentlemen, whether a little or a lot according to the part that has been set ". (Qur'an, Al-Nisa: 7). LikewiseBentam's it is stated in QS. Al-Anfal: 75, "People who are related are, in part, more entitled to each other in the book of God ". (Surat al-Anfal: 75). (Khisni, 2017)

Legitimate marriages lead to mutual legal relations inherit between husband and wife. A legal marriage is a marriage the terms and conditions are met, both according to the provisions of religious law and administrative provisions as regulated in legislation applicable. Regarding these administrative conditions, there is still dissent. Some call it mere record-keeping, but there are some opinions that call it a condition if not being met resulted in an illegitimate marriage. Indonesian marriage law seems to provide some leeway in this regard. That is, which becomes the size The validity of the marriage is not an administrative requirement, however religious law provisions. But it must be recognized that this administrative provision. It is an 
important (urgent) because, with the evidence of recording This administration, a marriage has legal force. Recording marriage is very necessary to prove legally formal, that two people have been married (Khisni, 2017). Islamic inheritance apportionment as follow:

TABLE III ISLAMIC INHERITANCE APPORTIONMENT

\begin{tabular}{|c|c|}
\hline $\begin{array}{l}\text { Inheritance } \\
\text { Law }\end{array}$ & Inheritance Apportionment \\
\hline $\begin{array}{l}\text { Islamic } \\
\text { Inheritance }\end{array}$ & $\begin{array}{l}\text { Half } \\
\text { A husband whose wife died. The condition is that he does not have } \\
\text { offspring (male or female), even though the offspring are stepchildren. } \\
\text { Biological daughter. The condition is that he does not have a son and the } \\
\text { daughter is an only child. } \\
\text { Granddaughter of a son's offspring. The condition is that the grandchild } \\
\text { does not have a son, is the only grandson (only), and does not have a } \\
\text { daughter or son. } \\
\text { Female siblings. The condition is that the sibling is alone and has no } \\
\text { other siblings. He also does not have a father or grandfather or } \\
\text { descendant (son or daughter) } \\
\text { A father's sister. The condition is that he has no siblings (only one) and } \\
\text { has no siblings. He also doesn't have a father or grandfather. } \\
\text { A quarter } \\
\text { Highth } \\
\text { Husband with children or grandchildren, } \\
\text { a wife without children or grandchildren of sons. } \\
\text { A third }\end{array}$ \\
\hline
\end{tabular}




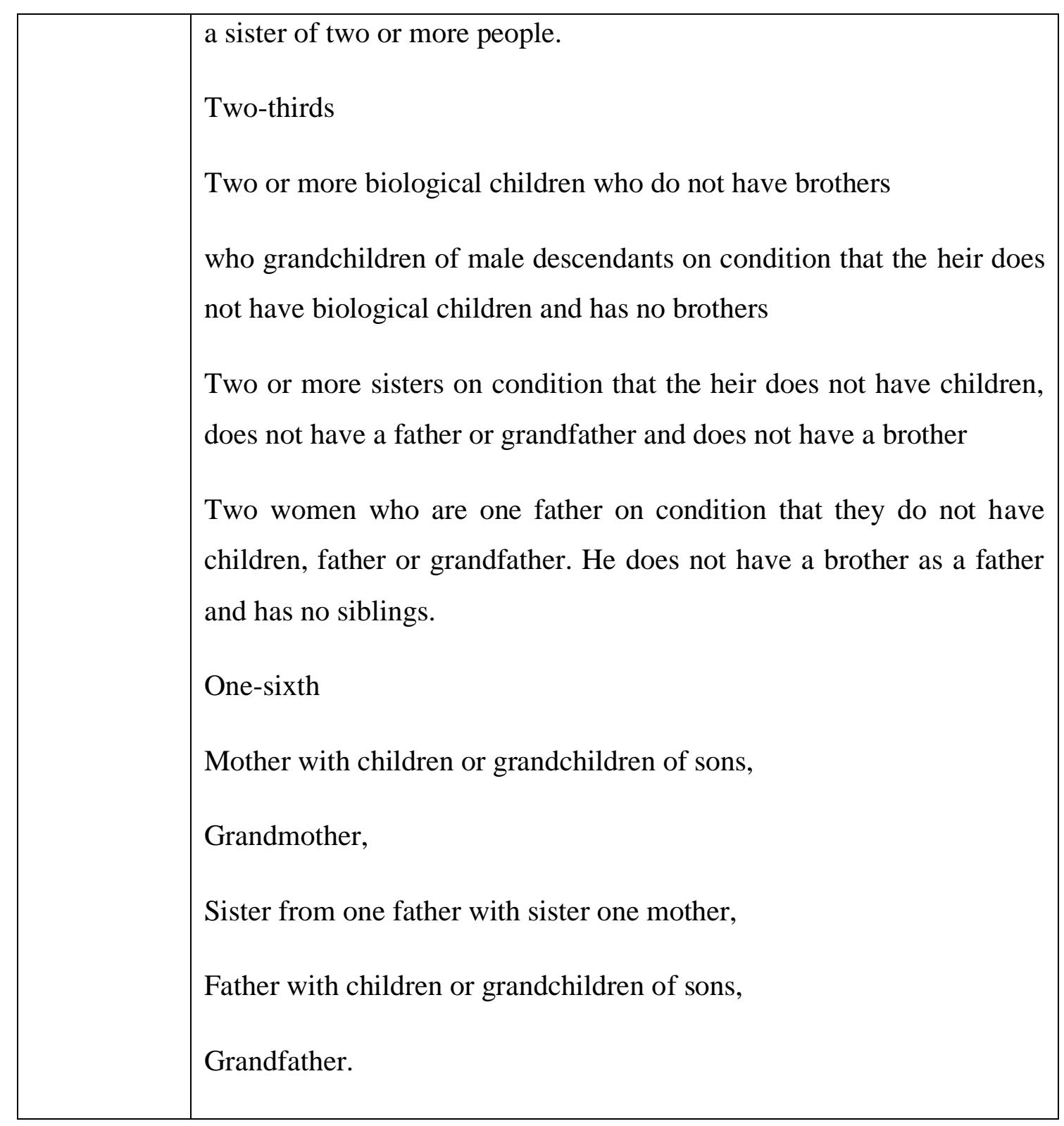

\section{DISCUSSION}

Inheritance law enforcement in Bentham's perspective is found the most objective basis is to see whether there are certain policies or actions that bring benefits or beneficial results or vice versa, contrary to the people involved. The results from its application are profusely, profusely happiness, and increasingly less suffering. And conversely consider bad if applying it produces an unfair, a loss, and only adds to suffering.

Which one is the fairest inheritance law for Indonesian people, civil inheritance law, customary law, or Islamic inheritance law? According to Bentham's theory, the law that brings benefits or beneficial results is the fairest. It means that no one inheritance law is the fairest for Indonesian people. All of the inheritance law is the fairest, depend on the people that use it. Civil 
inheritance law is fair if used for those who use it, Islamic inheritance law is fair to those who are Muslim and customary inheritance law is fair for those who apply it.

It is can be analogized with blood groups. There are blood groups of $\mathrm{A}, \mathrm{B}, \mathrm{AB}$, or O. Which one is the best? No one is the best. All of the blood groups are the best, depend on the human who suitable for it. The practice of distributing inheritance assets in Indonesian society is generally of two kinds, namely firstly if there is no conflict between heirs divided by a way of peace by the heirs themselves, whereas if there is a conflict between the heirs about the position of the heirs and the number of parts of each heir is distributed through the court.

\section{The Perspective of Islamic Inheritance Law}

\section{The Practice of Sharing Through Peace}

The practice of distributing inheritance through peace by means of deliberation among these heirs in Islamic law may and does not conflict with Islamic law, distribution in this way is carried out by many Indonesian Islamic communities, as studies conducted by Amir Syarifuddi, in the Sumaterta area Barat (Minangkabau), Zainuddin Ali in Sulawesi, Abdul Ghofur Anshori in Bantul Jogyakarta, Otje Saalman in Cirebon, Komari in Magetan East Java.201.

In Islamic law peace, in general, is to resolve problems, both those that have been disputes and disputes that have not yet occurred. The peace of the heirs to settle the distribution of inheritance has the aim to avoid future disputes between the heirs as children or close relatives of the heir. Even settlement with this peace the heirs do not need evidence and the heirs get the freedom to find an agreed solution in order to complete the distribution of inheritance.

Peace in Islamic law terminology is called Al-Shulh, even in Islamic law al-shluh or this peace has become the rule of ushul figh, which is called Al-suhulh Sayyid al-ahkam, meaning that peace is the peak of all laws, according to Syahrizal Abbas202 that choosing peace based on consideration (1). Can decide the parties, and no one feels disadvantaged and feels win or lose in the settlement, (2). With this peace can deliver peace of heart and satisfaction and strengthen friendship, and (3). Done voluntarily, there is no coercion, and the heirs make agreements to bring about peace.

A settlement with peace is recommended by Allah SWT, as in the Qur'an An-Nisa letter 'verse 128, that peace is a good deed. Even Abu Hurairah narrated the hadith of the Prophet Muhammad SAW said that peace between the Muslims is permissible, except peace which forbids something that is halal or ignites something that is haram. Furthermore Muhammad 
Rawwas Qal'ahji peace about the treasure there are two kinds namely peace renege that is illegal it seems that there is recognition of a person as the first party, regarding ownership of the property that is authorized by a third party, while the second party is not aware of the existence of that right. Then a peace occurs in which the second party surrenders the assets recognized by the first party. Whereas the second is peace recognition, this agreement is like the existence of recognition that the property under his control turns out to belong to someone else, and he does not want to return, then a peace agreement is held that he is willing to return some of the property of that other person.

In Islamic law there are three kinds of elements or pillars of peace that must be carried out by parties who have problems, the first element is lafazd is the words or deeds of both parties who hold the peace. Lafazd consists of consent and qobul. Ijab means a statement from one of the parties to a peace agreement, like we made peace with you by paying a debt of one thousand rupiahs, while Kabul is a statement of acceptance or approval of peace, both verbally and with actions to make peace. With the birth of the peace agreement, a legal bond was formed between the peace actors, each of which was obliged to carry out the peace agreement he agreed upon, and each party could not cancel unilaterally if a cancellation had to occur for both parties.

\section{Distribution of Inheritance through the Court}

The distribution of inheritance assets through the court is conducted by the court of the first instance, court of appeal and court of cassation, but the verdict of the court of first instance and appeal can not be said to have become jurisprudence, the meaning cannot be used as a basis for decisions by the court of the first instance and other appellate levels. Whereas the verdict at the Supreme Court is the jurisprudence. In this connection, only the Supreme Court's jurisprudence will be analyzed.

Generally in resolving inheritance disputes, the Supreme Court refers to the Compilation of Islamic Law. Reference to heirs to article 174, article 176, article 177, article 178, article 179, article 180, article 181, and article 182. These articles regulate legal norms, first if the heirs consisting only of sons all sons and daughters of inheritance are divided among the two children, with the stipulation that the ratio of boys and girls is two to one (2: 1). Second, if the heir consists of a daughter, he gets $1 / 2$ (half) the inheritance of leftover dirt as a rad, while if two or more daughters get $2 / 3$ (two thirds) plus the remainder as rad with the same variety. The three heirs of the child do not veil the father, widow mother, and widower of the heir, but veil the brother. The four descendants of the child substitute, but the portion may not exceed the heirs who as a is equal to the person he has replaced. 
The decision of the Supreme Court as jurisprudence Number 316K / AG / 1998, dated September 28, 1999. of the heirs who left one son and two daughters with each portion of a son receiving part 2/4 (two quarters),) and two daughters each get $1 / 4$ (a quarter) share. In addition to the decision of the Supreme Court regarding the portion of boys and girls two to one (2: 1) including the decision of the Supreme Court No. 211K / AG / 2003, dated January 4, 2008, the decision of the Supreme Court Number 145 / AG / 1993, dated March 30 1994. Decisions that stipulate that the proportion of boys and girls is one to two (2: 1), if examined from the decisions of the Supreme Court there are still many. Thus the Supreme Court still argues for the provisions of the Qur'an and the Compilation of Islamic Law, where the share of boys and girls remains two to one (2: 1). The decision has not undergone a change even though the culture of the Indonesian nation was not the same as the culture of the Arabs at the time the Qur'an was revealed, that Indonesian culture between men and women both made a living for their families, but different responsibilities men were responsible looking outside (public family) and women in the family (domestic family), and both help each other to make a living.

Besides that, there is a decision from Ujung Pandang Religious Court Number 230 / Pdt.G / 2000 / PA. Mks, dated November 14, 1999., who decided on a dispute over inheritance cases, the share of boys was equated with the portion of girls, with the consideration that in general, the distribution of inheritance assets in the people of South Sulawesi applies the same portion between boys and girls. In addition, there is an agreement between the plaintiffs and the Defendant, in which the distribution of inheritance will not differentiate between men and women.

In Supreme Court's jurisprudence about girls who veil or close relatives, there are still variations, there are still daughters who do not cover (hijab) siblings, and there are also decisions of girls who veil (close) relatives of the heirs. Al-Qur'an Surat An-Nisa 'verse 176 includes girls 215 This second view of the Supreme Court is actually an Indonesian culture that adopts a bilateral or parental inheritance legal system developed by Hazairin in which children, both boys, and girls are the first priority group who covered the second group, namely the brothers.

In the Supreme Court jurisprudence concerning substitute heirs generally based on article 185 Compilation of Islamic Law (KHI), but the parts of substitute heirs are still varied, because Article 185 Paragraph (2) allows multiple interpretations, namely the first part of substitute heirs must not exceed from the part of the heirs which is the same as the one replaced. In 
accordance with the article. The two parts of the surrogate heirs are more than those of the heirs who are equal to those who are replaced by the successor heirs.

\section{Prospective Customary Inheritance Law}

Indigenous inheritance law in Indonesia has three systems, namely the patrilineal inheritance legal system, the matrilineal system, and the bilateral or parental system. The three inheritance legal systems only apply to Indonesian citizens who do not adhere to the Islamic religion, because citizens who are Muslims apply Islamic inheritance law (see article 49 of Law No.7 / 19789 jo Law No. 3/2006 and the law Law No. 50/2009).

Customary law has a dynamic-plastic nature because it must pay attention to the needs of the community, while sociologically the community always develops and changes to find a suitable form and deviates from traditional-original customary law influenced by the family system, especially those that are unilateral, as well as bilateral systems, so that the three customary inheritance legal systems are moving towards pure, law, it is as said by Daniel S. Lev that the Customary law on inheritance is extended to the Batak people of North Sumatra who embrace patrilineal which further all Indonesian groups (Lev., 1973, p. 41).

In his dissertation Sacipta Rahardjo argued that the legal changes that occur are a fact of such a situation, namely the value of the change is felt to be very large in the Customary legal environment that favors the patrilineal line, as well as those who adhere to the matrilineal line, while those who follow the bilateral or parental lines the change is almost not felt (Rahardjo, 1979, p. 183).

Renewal or change of Customary law towards a parental or bilateral system is carried out through the Supreme Court jurisprudence. The Supreme Court as a judicial institution has a very important role in changing the customary legal system because the judge as a person who resolves disputes for justice seekers is also a philosopher who functions as finding the law and developing and changing the law in accordance with developments in society. This is in accordance with the demands of the Judicial Power Law that judges must be responsive to the problems of changes that occur in the community, which subsequently results of observations of these changes are made concrete in the decision, as the judge's work in taking steps towards law according to conditions and community needs.

In the jurisprudence of the Supreme Court, there have been many changes or reforms of traditional patrilineal and matrilineal customary laws that lead to bilateral or parental, as in the Tapanuli region of North Sumatra in traditional customary law, wives and daughters open heirs, 
but in the development there has been a lot of jurisprudence of the Supreme Court that a girl's position is the same as the son of her father, such as the decision of the Supreme Court Number 170.K / Sip / 1961, November 1, 1961.

Likewise, the Supreme Court jurisprudence Number 182.k / Sip / 1970 dated March 10, 1971, that the ruling was a widow and male and female children as heirs of his parents. In addition, in the jurisprudence of the Supreme Court there are still many that renew the traditional customary law from the patrilineal legal system to a bilateral or parental legal system.

\section{Prospective Legal System for Civil Heritage (BW)}

BW's civil law applies in Indonesia based on the principle of concordance and through adjustments as necessary to the condition of the Dutch East Indies (Indonesia) then applied in Indonesia, including the inheritance law. BW West civil law, especially its inheritance law, although it is not in accordance with the culture of the Indonesian people, but before there was a national inheritance law and was applied comprehensively for the Indonesian people for a while BW Western civil inheritance law was still treated, in order to avoid a legal vacuum, even though the government and The House of Representatives as a legislator is aware of it, but has not been able to make national inheritance law as the marriage law in Law Number 1 of 1974 concerning Marriage. This BW West civil inheritance law initially applied to the Dutch and Europeans, who were in Indonesia, then expanded to foreigners, except for Arabs who were Muslim. So the law of inheritance of the Western Pedata of BW applies to people of foreign descent who are not Muslim, such as Europeans, Chinese, Thailand, Japanese and others.

Broadly speaking, Western inheritance law (BW) also adheres to a bilateral or parental system, but European culture is different from Indonesia, if European culture adheres to an individual system, so that the heir has the right to give his wealth to anyone, whereas in the Islamic legal system and Customary law not so. Islam teaches that wealth is a mandate from God, so humans do not have the right as they wish to transfer it to other people, even though their offspring. He must follow the will of God Almighty, which has been specified in His Book.

Whereas in Indonesian law, which varies from all legal norms which constitute an organized unity with each other in relation to each other between the legal sub-systems, including inheritance law, all the legal systems are Pancasila as its groundnorm. Therefore in the future law in Indonesia must be no exception, both laws and regulations that will apply to the future are considered to have fulfilled national aspirations as contained in the Pancasila and the 1945 
Constitution, 313 while the Barta $\mathrm{Bw}$ civil law which is not cultural the Indonesian nation and its ground state is not Pancasilia, although to this day they still apply to foreign descendants such as China, Japan, Thailand, etc. but are only temporary due to the transitional rules in the 1945 Constitution.

Therefore, Indonesian inheritance law based on Pancasila must refer to the precepts of Pancasila, meaning that the applicable inheritance law must not be in conflict with the Almighty God, civilized justice, Indonesian Unity, Democracy which is led by wisdom in the deliberation/representation and Social justice for all Indonesian people.

\section{CONCLUSION}

Inheritance law enforcement in Bentham's perspective is to bring benefits or beneficial results or vice versa, contrary to the people involved. The results from its application are profusely, profusely happiness, and increasingly less suffering. And conversely consider bad if applying it produces an unfair, a loss, and only adds to suffering. Which one is the fairest inheritance law for Indonesian people, civil inheritance law, customary law, or Islamic inheritance law? According to Bentham's theory, the law that brings benefits or beneficial results is the fairest. It means that no one inheritance law is the fairest for Indonesian people. All of the inheritance law is the fairest, depend on the people that use it. Civil inheritance law is fair if used for those who use it, Islamic inheritance law is fair to those who are Muslim and customary inheritance law is fair for those who apply it.

The advice given is the application of inheritance law should be adjusted according to its usefulness. It mean that the application of inheritance law should give the benefit for the heir.

\section{REFERENCES}

A.Pitlo. (1986). Hukum Waris Menurut Kitab Undang-Undang Hukum Perdata Belanda. Jakarta: PT.Intermasa.

Bentham, J. (2000). An Introduction to the Principles of Morals and Legislation. Kitchener: Batoche Books.

BPS. (2016). Penduduk Menurut Wilayah Dan Agama Yang Dianut. Diambil kembali dari Sensus Penduduk 2016: http://www.bps.go.id/website/pdf_publikasi/watermark_Proyeksi Penduduk Indonesia 2010-2035.pdf.

Creswell, J. W. (2014). Research Design: Qualitative, Quantitative \& Mixed Methods Approaches. United Kingdom: SAGE Publications.

Keraf, S. (1998). Etika Bisnis Tuntunan dan Relevansinya, Kanisius. Yogyakarta: PT Kanisius. Khisni, H. (2017). Hukum Waris Islam.

Lev., D. S. (1973). Lembaga Peradilan dan Kultur Hukum Indonesia. Jakarta: Prisma. 
Prasetya, E. (2017). Dari 17.504 Pulau Di Indonesia, 16.056 Telah Diverifikasi PBB. Diambil kembali dari Merdeka.com: https://www.merdeka.com/peristiwa/dari-17504-pulau-diindonesia-16056-telah-diverifikasi-pbb.html

Rahardjo, S. (1979). Huium dan Perubahan Sosial. Bandung: Disertasi Alumni.

Ramulyo, M. I. (2004). Perbandingan Hukum Kewarisan Islam dengan Kewarisan Kitab Undang-undang Hukum Perdata. Jakarta: Sinar Grafika.

Rasjidi, L., \& Putra, I. W. (1993). Hukum sebagai Suatu Sistem. Bandung: Remaja Rosdakarya. UN Convention on the Law of The Sea. (1982). UN Convention on the Law of The Sea. Diambil kembali dari https://www.un.org/Depts/los/convention_agreements/texts/unclos/part5.htm

Vartanian, T. P. (2011). Secondary Data Analysis. London: Oxford Unversity Pres.

World Intellectual Property Organization. (2016). Customary Law and Traditional Knowledge. Customary Law 7, no. 7, 1-4.

About Author: Rachmat Trijono is a senior researcher from the Ministry of Law and Human Rights. He was born on November 16th, 1964 in Purwokerto.

Inheritance Law Enforcement Is To Bring Benefits Or Beneficial Results 